\title{
Impact of Type 1 Diabetes Mellitus on Bone Health in Children
}

\author{
Marco Janner ${ }^{\mathrm{a}}$ Christoph Saner ${ }^{\mathrm{a}, \mathrm{b}}$ \\ aDivision of Paediatric Endocrinology, Diabetology and Metabolism, Department of Paediatrics, Inselspital, \\ Bern University Hospital, University of Bern, Bern, Switzerland; bepartment of Biomedical Research (DBMR), \\ University of Bern, Bern, Switzerland
}

\section{Keywords}

Type 1 diabetes mellitus · Bone mineral density ·

Microarchitecture · Osteoporosis · Bone turnover marker

\begin{abstract}
This paper gives an overview of the impact of type 1 diabetes on bone health in children and adolescents. Firstly, we analyse studies using dual X-ray absorptiometry to assess bone mineral content and bone mineral density. Then, we discuss modern, non-invasive techniques including peripheral quantitative computer tomography (pQCT) and high-resolution PQCT for the detailed assessment of bone health aspects including bone mass, bone geometry, bone microarchitecture, and bone strength. Thereafter, we explore some of the mechanisms that are responsible for diabetic bone disease in children, like low bone turnover and high sclerostin levels. Finally, we summarize some of the evidence for the importance of microvascular disease in the pathophysiology of diabetic bone disease.

(c) 2021 S. Karger AG, Basel
\end{abstract}

\section{Introduction}

The global prevalence and incidence of type 1 diabetes mellitus (T1DM) in children and adults is increasing [1]. More than 1 million children were affected by T1DM by 2019 , and the greatest increase in incidence was observed in children younger than 5 years [2]. Subsequent costs related to T1DM in youth in the USA have mounted, mainly due to insulin prices and a growing demand and utilization of diabetes technology [3]. In adults with T1DM, the main determinants for rising economic and health care burden are increased morbidity and mortality due to microvascular and macrovascular disease [2].

Osteoporosis is a major health problem that is characterized by low bone mineral density (BMD), altered microarchitecture, and subsequent increased fracture risk. Globally, approximately 9 million major osteoporotic fractures occur each year [4], reflected in a lifetime risk for major osteoporotic fractures of $30 \%$ for women and $15 \%$ for men [5].

The bone phenotype of adults with T1DM is characterized by 4 elements: Firstly, low BMD [6]; secondly, disruption of the microarchitecture [7]; thirdly, increased fracture risk [8] resulting in 6-fold increased prevalence of hip fractures in individuals with T1DM compared to healthy adults [9], and finally, a low bone turnover status $[8,10]$.

Correspondence to:

Marco Janner, marco.janner@insel.ch 
In adults, the evidence for an adverse impact of T1DM on bone mass, bone architecture, and bone strength is compelling. In contrast, results in children are conflicting: a meta-analysis [11] including 9 studies in children with T1DM showed a lower BMD Z-score in 5 [12-16], whereas 4 studies did not show any difference in BMD [17-20]. Another systematic review including 25 studies showed that the influence of T1DM was related to gender and younger age of disease onset (i.e., below 20 years) and that the impact of T1DM was beyond that expected for known age- and gender disparities in healthy controls [6]. However, BMD in these studies was assessed by dual Xray absorptiometry (DXA).

The major limitation of DXA in children and adults is that it measures bone mineral content (BMC) and not true volumetric BMD (vBMD). As a surrogate, $\mathrm{BMC}$ is divided by the area investigated to reveal areal $\mathrm{BMD}$, which becomes a surrogate of true BMD. Consequently, areal BMD underestimates the $\mathrm{vBMD}$ of small bones, whereas it overestimates vBMD in children with tall stature. In contrast, the method of peripheral quantitative computed tomography (pQCT) directly calculates vBMD, measures the cortical and trabecular compartment, and assesses bone geometry as well as the bonemuscle unit [21]. Beyond pQCT, high-resolution pQCT (HRpQCT) further enables the measurement of bone microarchitecture and bone strength, calculated via micro-finite element analysis [21]. During the last 15 years, studies investigating pQCT [22-26] and HRpQCT [2628 ] in children with T1DM have been published and provided results for biomechanically relevant determinants of bone quality including vBMD, bone microarchitecture and bone strength. Another reason for conflicting study results based on DXA measures may be sample size. However, a very recent, comprehensive meta-analysis including 46 studies with 2,617 cases and 3,851 controls showed that BMD measured with DXA (total body, lumbar spine, femur), pQCT (radius and tibia) and quantitative ultrasound of the calcaneus and phalanx was substantially lower in children with T1DM compared to controls [27].

With this mini-review, we aim to give a recent update on the impact of T1DM on bone health in children and adolescents with T1DM. Firstly, we discuss the impact of T1DM on bone mass, including publications since 2004 when $\mathrm{PQCT}$ and HRpQCT have been used to assess bone geometry and microarchitecture. Secondly, we describe the low bone turnover status and analyse important issues of its pathophysiology including the possible role of microvascular disease.

\section{Physiology of Bone Mass Accrual and Methods of Assessment}

\section{Physiology of Bone Mass Accrual in Children and} Adolescents

Bone mass accrual in childhood is a major determinant of peak bone mass (PBM) and later fracture risk [28]. Bone mass increases continuously during childhood followed by a steep increase during puberty [29]. In girls, peak bone mineral accrual occurs 2 years earlier than in boys, approximately 0.7 years after reaching peak height velocity, and synchronously with menarche [29]. Total $\mathrm{BMC}$ reaches a plateau 6 years after peak height velocity and PBM is attained by the end of the second or early in the third decade [30]. Several factors are related to higher PBM in males than females: firstly, males have larger bones. Secondly, males have a higher cortical thickness due to periosteal bone apposition in contrast to endosteal bone apposition in females during sexual maturation. Thirdly, BMD gain in males continues in boys after puberty compared to a reduced BMD gain by 16 years of age in females [31]. The physiology of bone mass accrual highlights the importance of the adolescent period for PBM acquisition [32].

\section{Assessment of Bone Strength in Children and}

Adolescents

Bone strength depends on BMD, bone dimensions (including bone diameter and cortical thickness), bone architecture, and tissue properties such as the degree of mineralization, the rate of bone remodelling and accumulation of micro-trauma [33]. BMD can be measured by 5 non-invasive techniques. DXA measures BMC, projected bone area and areal BMD. Areal BMD depends on bone size, and therefore underestimates true vBMD in short children with small bones. Quantitative computed tomography of the spine and pQCT at different sites of the radius and tibia allow the distinct measurement of true $\mathrm{vBMD}$ of the trabecular and cortical compartment, the degree of mineralization and an assessment of the cortical geometry. The resolution of pQCT of $400 \mu \mathrm{m}$ is insufficient for an accurate assessment of bone microarchitecture as the trabecula are separated by measures of 300 $1,000 \mu \mathrm{m}$. In contrast, HRpQCT provides a resolution of $60-80 \mu \mathrm{m}$ that is close to that of micro-CT. In addition, the construction of micro-finite element models allows the estimation of bone strength. Micro-finite element analysis models the mechanical properties of cortical and trabecular bone under different forces. Quantitative ultrasound has a good correlation to DXA measurements 
to estimate BMD at different sites (calcaneus, phalanges, patella), and allows the assessment of mechanical properties of bone. Finally, skeletal MRI can be used to assess trabecular and cortical bone structure, revealing an excellent agreement with DXA, pQCT, and HRpQCT. However, its use is largely limited to research purposes.

\section{DXA-Related Bone Health Results in Children with T1DM, the Role of Metabolic Control, and Associations with Future Fracture Risk}

\section{Bone Mass Measured by DXA in Children with T1DM}

The literature on DXA measurements to assess bone mass in children and adolescents with T1DM is conflicting. The most recent, comprehensive meta-analysis including 2,617 children with T1DM showed significantly lower mean total body BMD, lumbar spine BMD, and femur neck BMD $\left(-0.04 \mathrm{~kg} / \mathrm{cm}^{2},-0.02 \mathrm{~g} / \mathrm{cm}^{2}\right.$ and -0.04 $\mathrm{g} / \mathrm{cm}^{2}$, respectively) compared to 3,851 healthy controls [27]. Some smaller cross-sectional studies in children with T1DM revealed lower total body BMD Z-scores compared to controls [34], lower total body less head (TBLH) BMC and aBMC at the femoral neck, lower tibial cortical vBMD [35], lower total body, and lumbar spine BMC [36] when compared to age-matched reference data. We are aware of only 1 longitudinal study over 10 years in a small group of children with T1DM, revealing a lower total body BMD and lumbar spine BMD, when compared to age-matched reference data [37]. In this study, there was no deterioration of BMD over time and no correlation with $\mathrm{HbA}_{1 \mathrm{c}}$ [37]. However, 1 study showed a reduced bone mass accrual in subjects with poor metabolic control 1 year following diagnosis of T1DM [35].

In contrast, a large Danish study showed even higher TBLH BMD Z-scores at near-final height compared to age-matched reference data, independently of glycaemic control [34]. Similarly, another Danish cohort study [38] revealed a trend to higher TBLH BMD $Z$-scores in boys. In this study, however, there was a negative correlation between glycaemic control and BMD Z-score [38]. We are aware of 2 earlier cross-sectional studies including more than a 100 participants with overall poor metabolic control as assessed by $\mathrm{HbA}_{1 \mathrm{c}}$, showing lower BMD Zscores at the lumbar spine $[14,15]$.

\section{Fracture Risk in Children with T1DM}

In adults, there is robust evidence for increased fracture risk in individuals with T1DM [39-43]. In children and adolescents with T1DM, data on fracture risk are scanty. In a population-based cohort study with 334,266 participants (30,394 with T1DM) between 0 and 83 years, the hazard ratio for incident fractures in males and females with T1DM below age 20 years was 1.14 and 1.35 , respectively [42]. Beyond a direct effect from diabetes, fracture risk in childhood and adolescence may be mediated by lower bone mass in youth with T1DM. A prospective cohort study from the ALSPAC cohort in more than 6000 healthy children showed an $89 \%$ increased fracture risk per SD decrease in size-adjusted BMC [44]. In the same line of evidence, a meta-analysis showed that the standardized mean difference for bone mass in children with and without fractures was -0.32 suggesting that bone mass is related to fracture risk [45].

\section{Outcomes of Bone Geometry and Microarchitecture by PQCT, HRpQCT, and MRI in Children with T1DM}

The assessment of trabecular and cortical vBMD, of the microarchitecture and bone strength in adults with T1DM using non-invasive techniques as pQCT and HRpQCT showed reduced BMD and compromised bone architecture $[8,46]$. Interestingly, recent studies showed that microvascular disease may play a role in the pathogenesis of diabetic bone disease [7, 47].

\section{pQCT in Children with T1DM}

We found 6 studies in children and adolescents with type 1 diabetes using both pQCT and DXA to assess $\mathrm{BMD}$, bone geometry, and microarchitecture $[15,22,23$, $25,48,49]$, and 3 studies using solely pQCT $[26,50,51]$. A summary of the results is given in Table 1. Whereas DXA measurements showed conflicting results with lower bone mass in 4 studies and no difference in bone mass in 2 studies, pQCT measurements revealed a reduction of vBMD affecting the trabecular compartment in 7 studies $[15,22,23,25,48-50]$. In contrast, Jaworski et al. [51] measured normal $Z$-scores for age in a small group of children with T1DM without a control group. Finally, Bechtold et al. [26] found a reduced cortical vBMD without alteration of the trabecular compartment across puberty. In this study, a subgroup analysis revealed that the participants with more severely reduced cortical vBMD were significantly younger. We think that there are at least 2 possible explanations for the conflicting results between studies using DXA versus pQCT: Firstly, DXA does not allow the assessment of the cortical and the trabecular compartment separately. Since the cortical compartment makes up to $80 \%$ of total bone mass, early re- 
Table 1. Characteristics of selected studies assessing bone mass and microarchitecture by DXA and pQCT in children

\begin{tabular}{|c|c|c|c|c|c|c|c|c|}
\hline Study & Design & Participants & $\begin{array}{l}\text { Age, } \\
\text { years }\end{array}$ & $\begin{array}{l}\text { Diabetes } \\
\text { duration, } \\
\text { years }\end{array}$ & $\begin{array}{l}\mathrm{HbA} 1 \mathrm{c} \\
\%\end{array}$ & Technique & Sites & Main findings \\
\hline Wagh et al. [25] & Cross-sectional & $\begin{array}{l}\text { T1DM } n=137 \\
\text { controls } n=68\end{array}$ & $\begin{array}{l}13.1 \pm 3.2 \\
13.0 \pm 2.7\end{array}$ & ng & $10.7 \pm 1.9$ & $\begin{array}{l}\text { DXA } \\
\text { pQCT }\end{array}$ & $\begin{array}{l}\text { LS } \\
\text { Distal radius }\end{array}$ & $\begin{array}{l}\text { No significant difference in LS } \\
\text { BMC and BMD, lower TBS } \\
\text { Lower trabecular vBMD }\end{array}$ \\
\hline $\begin{array}{l}\text { Dongare-Bhor } \\
\text { et al. [15] }\end{array}$ & Cross-sectional & $\begin{array}{l}\text { T1DM } n=251 \\
\text { controls } n=250\end{array}$ & $\begin{array}{l}10.8 \pm 4.3 \\
10.3 \pm 3.6\end{array}$ & $\mathrm{ng}$ & $\begin{array}{l}9.5 \pm 1.9 \text { boys } \\
9.9 \pm 2.2 \text { girls }\end{array}$ & $\begin{array}{l}\text { DXA } \\
\text { PQCT }\end{array}$ & $\begin{array}{l}\text { TBLH, LS } \\
\text { Radius }\end{array}$ & $\begin{array}{l}\text { TBLH aBMD lower in T1DM, LSB- } \\
\text { MAD lower in T1DM } \\
\text { Trabecular vBMD, total VBMD } \\
\text { lower in T1DM } \\
\text { Cortical vBMD higher in T1DM }\end{array}$ \\
\hline $\begin{array}{l}\text { Jaworski } \\
\text { et al. [51] }\end{array}$ & Cross-sectional & $\begin{array}{l}\mathrm{T} 1 \mathrm{DM} n=39 \\
\text { no controls }\end{array}$ & $11.9-18.0$ & $1.3-6.2$ & $\begin{array}{l}7.6 \pm 0.85 \text { girls } \\
7.7 \pm 1.58 \text { boys }\end{array}$ & $\mathrm{pQCT}$ & $\begin{array}{l}\text { Radius } 4 \% \\
\text { and } 66 \%\end{array}$ & $\begin{array}{l}\text { Normal z-scores for age, girls: } \\
\text { decreased ratio of cortical BA/ } \\
\text { muscle area }\end{array}$ \\
\hline Weber et al. [35] & $\begin{array}{l}\text { Longitudinal } \\
\text { over } 1 \text { year } \\
\text { after diagnosis }\end{array}$ & $\mathrm{T1DM} n=36$ & $7-17$ & ng & $7-12.9$ & $\begin{array}{l}\text { DXA } \\
\text { pQCT }\end{array}$ & $\begin{array}{l}\text { TBLH BMC } \\
\text { LS aBMD } \\
\text { FN aBMD } \\
\text { Tibia } \\
\text { Distal radius }\end{array}$ & $\begin{array}{l}\text { Lower TBLH BMC, FN aBMD } \\
\text { Bone accrual worse with poor } \\
\text { HbA1c } \\
\text { Lower tibial cortical vBMD }\end{array}$ \\
\hline $\begin{array}{l}\text { Maratova } \\
\text { et al. [50] }\end{array}$ & Cross-sectional & $\begin{array}{l}\text { T1DM } n=95 \\
\text { no controls }\end{array}$ & $16.2 \pm 1.2$ & $7.8 \pm 4.8$ & $8.5 \pm 3.5$ & $\mathrm{pQCT}$ & Tibia & $\begin{array}{l}\text { Trabecular BMD, increased corti- } \\
\text { cal BMD in T1DM }\end{array}$ \\
\hline Saha et al. [48] & Cross-sectional & $\begin{array}{l}\operatorname{T1DM} n=48, \\
\text { matched controls } n=48\end{array}$ & $\begin{array}{l}\text { Girls } 12.2-17.8 \\
\text { Boys } 12-17.4 \\
\text { Girls } 12.7-16.7 \\
\text { Boys } 12.7-16.8\end{array}$ & $1-13.5$ & $7.5-12.3$ & DXA pQCT & $\begin{array}{l}\text { LS, proximal } \\
\text { femur } \\
\text { Distal radius, } \\
\text { radius shaft }\end{array}$ & $\begin{array}{l}\text { No difference in DXA } \\
\text { Reduced bone mass and size, } \\
\text { reduced trabecular and cortical } \\
\text { vBMD }\end{array}$ \\
\hline $\begin{array}{l}\text { Moyer-Milleur } \\
\text { et al. [49] }\end{array}$ & Cross-sectional & $\begin{array}{l}\text { T1DM } n=11 \\
\text { controls } n=10\end{array}$ & $\begin{array}{l}12.9 \pm 1.0 \\
13.1 \pm 1.1\end{array}$ & $8.1 \pm 1.04$ & $5.9 \pm 3.7$ & $\begin{array}{l}\text { DXA } \\
\text { pQCT }\end{array}$ & $\begin{array}{l}\text { TBLH, FN, LS } \\
\text { Tibia }\end{array}$ & $\begin{array}{l}\text { Bone mass and bone density } \\
\text { reduced at all sites } \\
\text { Reduced trabecular vBMD }\end{array}$ \\
\hline $\begin{array}{l}\text { Bechtold } \\
\text { et al. [26] }\end{array}$ & Cross-sectional & $\begin{array}{l}\text { T1DM } n=88 \text { (42 girls), } \\
\text { no controls }\end{array}$ & $11.7 \pm 3.0$ & $5.6 \pm 3.7$ & & $\mathrm{pQCT}$ & $\begin{array}{l}\text { Proximal and } \\
\text { distal radius }\end{array}$ & $\begin{array}{l}\text { No differences compared to ref- } \\
\text { erence ranges, but reduced corti- } \\
\text { cal vBMD, total, cortical and mus- } \\
\text { cle CSA in subgroup with long } \\
\text { disease duration }\end{array}$ \\
\hline Heap et al. [23] & Cross-sectional & $\begin{array}{l}\text { T1DM } n=55 \\
\text { controls } n=95\end{array}$ & $\begin{array}{l}\text { Boys } 14.6 \pm 1.7 \\
\text { Girls } 14.7 \pm 1.9 \\
\text { Boys } 14.5 \pm 1.9 \\
\text { Girls } 14.8 \pm 1.5\end{array}$ & $1.1-10.3$ & $7.3-12$ & $\begin{array}{l}\text { DXA } \\
\text { pQCT }\end{array}$ & $\begin{array}{l}\text { TBLH, FN, LS } \\
\text { Tibia }\end{array}$ & $\begin{array}{l}\text { FN BMD lower, TB BMC and BMD } \\
\text { lower in T1DM } \\
\text { Trabecular vBMD lower in T1DM }\end{array}$ \\
\hline $\begin{array}{l}\text { Moyer-Milleur } \\
\text { et al. [22] }\end{array}$ & Cross-sectional & $\begin{array}{l}\text { T1DM } n=42, \\
\text { controls } n=199\end{array}$ & $\begin{array}{l}\text { Boys } 14.9 \pm 1.8 \\
\text { Girls } 14.1 \pm 1.8 \\
\text { Boys } 15 \pm 2.1 \\
\text { Girls } 15 \pm 1.9\end{array}$ & $8.2 \pm 1.2$ & $4.2 \pm 3.1$ & $\begin{array}{l}\text { DXA } \\
\text { pQCT }\end{array}$ & $\begin{array}{l}\text { TBLH, FN, LS } \\
\text { Tibia }\end{array}$ & $\begin{array}{l}\text { BA, BMC, BMD, BMAD lower in } \\
\text { T1DM; BA and BMAD lower after } \\
1 \text { yr compared to bone length. } \\
\text { Trabecular BA, trabecular BMC, } \\
\text { trabecular vBMD lower in T1DM }\end{array}$ \\
\hline
\end{tabular}

BA, bone area; BMAD, bone mineral apparent density; CSA, cross-sectional area; FN, femoral neck; LS, lumbar spine; TBS, trabecular bone score; aBMD, areal bone mineral density.

duction in trabecular volume and number may be missed by DXA [52]. Secondly, DXA measures areal bone density, which depends on bone size as discussed. Since children with type 1 diabetes may have a growth delay and reduced final height related to poor metabolic control, true volumetric density may be underestimated using DXA $[53,54]$. Further evidence for the impact of overall health on bone health is provided by a study by PhamShort et al. [24], which showed lower BMC at the radius measured by pQCT in children with T1DM and wellcontrolled celiac disease compared to children with T1DM without celiac disease. Finally, a recent compre- hensive meta-analysis showed that the mean differences in tibial trabecular vBMD and radial trabecular vBMD $\left(-11.32 \mathrm{~kg} / \mathrm{cm}^{3}\right.$ and $-0.91 \mathrm{~g} / \mathrm{cm}^{3}$, respectively) were significantly lower in youth with T1DM compared to controls [27].

\section{HRpQCT in Children with T1DM}

Three studies in children with type 1 diabetes using HRpQCT (Table 2) showed an altered microarchitecture that is consistent with increased skeletal fragility [55-57]. In 2 of them, DXA measurements did not show any difference in BMC and BMD in T1DM compared to con- 
Table 2. Characteristics of the studies assessing bone mass and microarchitecture by DXA, HRpQCT, and MRI in children with type 1 diabetes

\begin{tabular}{|c|c|c|c|c|c|c|c|c|}
\hline Study & Design & Participants & Age, yr & $\begin{array}{l}\text { Diabetes } \\
\text { duration, } \\
\text { years }\end{array}$ & $\begin{array}{l}\mathrm{HbA1c}, \\
\%\end{array}$ & Technique & Sites & Main findings \\
\hline $\begin{array}{l}\text { Devaraja } \\
\text { et al. [55] }\end{array}$ & Cross-sectional & $\begin{array}{l}\text { T1DM } n=22 \\
\text { controls } n=22\end{array}$ & $\begin{array}{l}13.8 \pm 1.2 \\
13.6 \pm 1.2\end{array}$ & $9.25 \pm 1.62$ & $7.4-8.4$ & $\begin{array}{l}\text { DXA } \\
\text { HRpQCT }\end{array}$ & $\begin{array}{l}\text { TBLH } \\
\text { Radius, tibia }\end{array}$ & $\begin{array}{l}\text { No difference in BMC and BMD } \\
\text { Radius: reduced trabecular number, increased } \\
\text { trabecular separation and inhomogeneity and } \\
\text { reduced failure load } \\
\text { Tibia: reduced trabecular thickness, reduced } \\
\text { failure load }\end{array}$ \\
\hline $\begin{array}{l}\text { Fuusager } \\
\text { et al. [56] }\end{array}$ & $\begin{array}{l}\text { Cross-sectional } \\
\text { (same cohort as } \\
\text { Fuusager et al. } \\
\text { [38]) }\end{array}$ & $\begin{array}{l}\text { T1DM } n=84 \\
\text { controls } n=55\end{array}$ & $\begin{array}{l}6.5-17.9 \\
6 . \pm 17.5\end{array}$ & $0.4-15.9$ & $5.9-11.8$ & HRpQCT & Radius, tibia & $\begin{array}{l}\text { Reduced failure load at both sites } \\
\text { Reduced cortical area, trabecular vBMD, } \\
\text { trabecular number; increased trabecular } \\
\text { inhomogeneity }\end{array}$ \\
\hline $\begin{array}{l}\text { Mitchell } \\
\text { et al. [57] }\end{array}$ & Cross-sectional & $\begin{array}{l}\text { T1DM girls, } n=62, \\
\text { controls } n=61\end{array}$ & $\begin{array}{l}13.6 \pm 1.7 \\
13.6 \pm 1.9\end{array}$ & $1.6-8.0$ & $8.6 \pm 1.3$ & $\begin{array}{l}\text { DXA } \\
\text { HRpQCT }\end{array}$ & $\begin{array}{l}\text { TBLH, LS, hip, } \\
\text { radius, tibia } \\
\text { Distal radius, } \\
\text { distal tibia }\end{array}$ & $\begin{array}{l}\text { No difference in BMD in DXA } \\
\text { Tibia: lower total trabecular BV/TV, higher } \\
\text { cortical porosity, reduced failure load } \\
\text { Radius: lower cortical vBMD }\end{array}$ \\
\hline $\begin{array}{l}\text { Chen } \\
\text { et al. [36] }\end{array}$ & Cross-sectional & $\begin{array}{l}\mathrm{T} 1 \mathrm{DM} n=32 \\
\text { controls }=26\end{array}$ & $\begin{array}{l}10.4-16.7 \\
10.2-17.8\end{array}$ & $3.1-12.4$ & $4.6-11.3$ & $\begin{array}{l}\text { DXA } \\
\text { MRI }\end{array}$ & $\begin{array}{l}\text { TBLH, LS } \\
\text { proximal tibia }\end{array}$ & $\begin{array}{l}\text { Lower BMD in T1DM } \\
\text { Lower trabecular volume, lower trabecular } \\
\text { number, higher trabecular separation }\end{array}$ \\
\hline
\end{tabular}

BA, bone area; BMAD, bone mineral apparent density; CSA, cross-sectional area; FN, femoral neck; LS, lumbar spine.

trols $[55,57]$. All 3 studies showed a significant association between altered bone microarchitecture and poor glycaemic control. Consistent with most of the studies using pQCT, the trabecular compartment was primarily affected, although 1 study also found reduced cortical area [56]. In addition, Mitchell et al. [57] showed decreased procollagen $1 \mathrm{~N}$-terminal peptide (P1NP), a marker of bone formation, in T1DM, whereas there was no difference in C-terminal telopeptide (CTX), a marker of bone resorption. In the same study, adjustment for IGF-1 Z-scores, which were lower in children with T1DM largely attenuated observed differences in microarchitecture due to T1DM status.

\section{Skeletal MRI in Children with T1DM}

To our best knowledge, there is only 1 small study with 32 children with T1DM compared to age-, and sexmatched healthy children, using skeletal MRI of the proximal tibia that shows a lower trabecular number, lower trabecular volume, and higher trabecular separation [36].

\section{Mechanisms Affecting Bone Health in T1DM}

The aforementioned studies using new non-invasive techniques to assess bone mass and strength have shown consistent evidence that children and adolescents with T1DM have profound alterations of bone microarchitec- ture and bone strength early in disease course. Mechanisms leading to this severe negative impact on bone health are complex and involve reduced bone turnover, altered osteocyte function, low IGF-1, low amylin, hyperglycaemia, advanced glycation end products as well as a disturbed PTH-vitamin D axis, inflammatory cytokines and eventually, microvascular disease. This topic has recently been exhaustively reviewed [8]. In the following, we will discuss the recent paediatric literature with focus on 4 issues: (1) reduced bone turnover due to impaired osteoblast function, (2) altered osteocyte function, (3) altered PTH-vitamin D axis, and (4) the possible role of microvascular disease (Fig. 1).

\section{Low Bone Turnover and Biochemical Markers in T1DM}

Diabetic bone disease is a low bone turnover condition that begins early in the disease course. A large meta-analysis including 66 studies, 21 of them in T1DM (7 studies in children), showed that osteocalcin as a bone formation marker and CTX were significantly lower in diabetics whereas sclerostin was significantly higher in diabetics than in controls [58]. Additionally, P1NP was lower in diabetics although it did not reach significance [58]. In a recent systematic review, however, only osteocalcin was found to be reduced with no difference in CTX and P1NP levels [59]. The same group found reduced osteocalcin and CTX in diabetic youth during partial remission [60], 


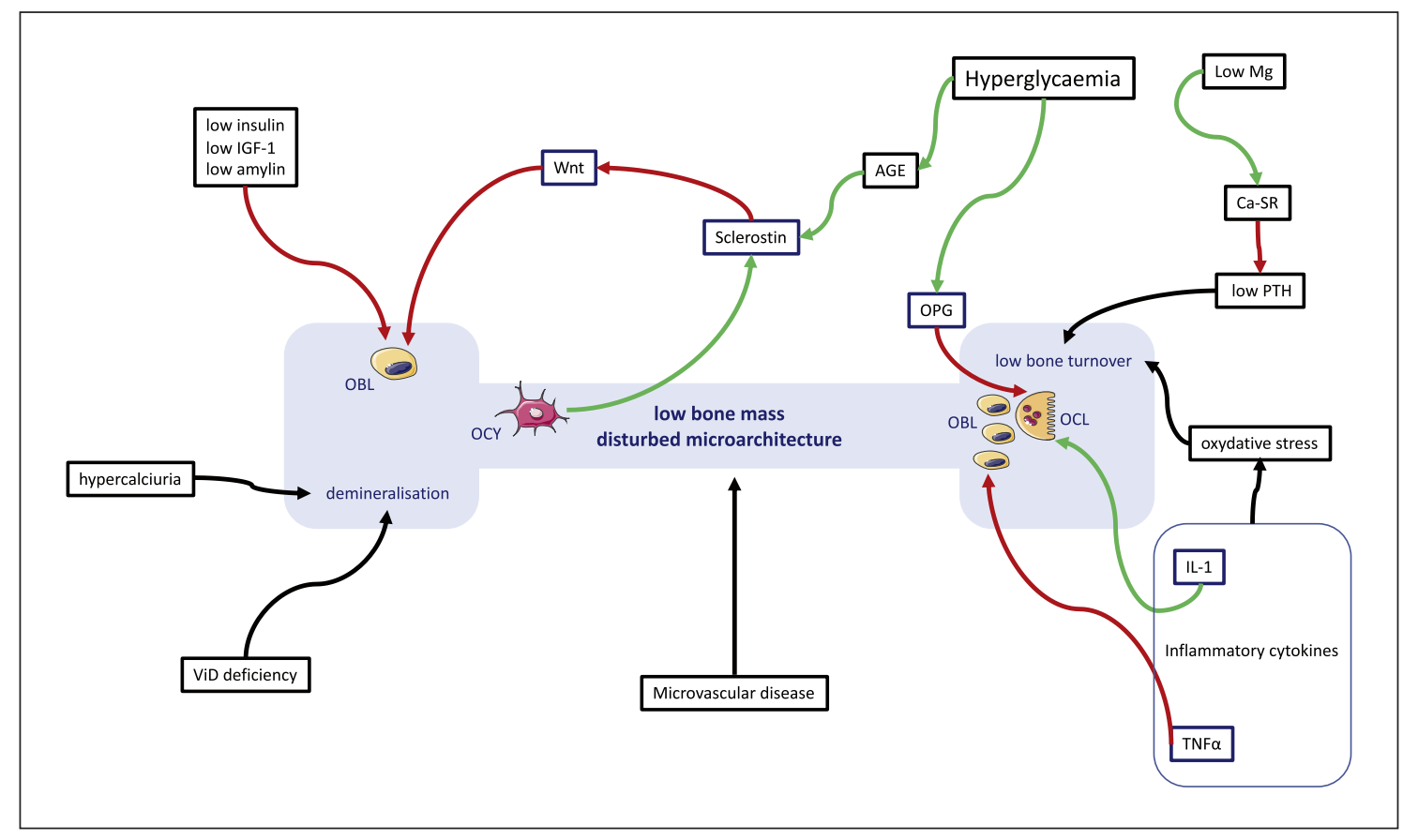

Fig. 1. Mechanisms contributing to diabetic bone disease in youth with type 1 diabetes. Diabetic bone disease in youth with T1DM is characterized by low bone mass, low bone turnover, demineralization, and a disturbed microarchitecture. The mechanisms leading to this comorbidity are complex and not fully understood. Nonetheless, various putative pathogenetic mechanisms are summarized in the figure above. Low insulin levels cause hyperglycaemia and negatively impact on osteoblast differentiation. Likewise, low IGF-1 and low amylin in T1DM inhibit osteoblast differentiation. Chronic hyperglycaemia increases concentration of AGEs, which stimulate sclerostin production by osteocytes. Sclerostin inhibits the canonical Wnt-signalling cascade, which is essential for osteoblast differentiation and function. In addition, glycosylation of type I collagen leads to impaired material strength. Also, hyperglycaemia contributes to chronic inflammation with increased local IL-1 and TNF- $\alpha$ levels promoting oxidative stress. IL-1 stimulates

indicating that low turnover status persisted during the remission of pancreatic beta-cell function. Consistent with this observation, 2 additional studies in youth with T1DM showed low osteocalcin and P1NP levels $[61,62]$. In addition, 1 study linked low P1NP to markers of oxidative stress [62].

Further determinants of low bone turnover include insulin deficiency, which by itself reduces osteoblast differentiation [63]. Another important factor for osteoblast recruitment is locally produced IGF-1 [64]. Low IGF-1 levels are present in T1DM and could be responsible for reduced osteoblast activity [57, 65]. Hyperglycaemia has been shown to increase the RANKL decoy receptor osteoprotegerin thereby reducing osteoclast differentiation osteoclast activity, whereas TNF- $\alpha$ inhibits osteoblast function. Finally, hyperglycaemia increases OPG in vitro resulting in reduced osteoclast differentiation and function. The effects of chronic hyperglycaemia add up to a low bone turnover status. Functional hypoparathyroidism because of hypomagnesaemia-induced reduced CaSR signalling further contributes to low bone turnover. Associated hypercalciuria, as well as vitamin D deficiency, are responsible for negative calcium balance and demineralization. Finally, microvascular disease seems to play a role in diabetic bone disease. Red arrows: negative effect, green arrows: positive effect. $\mathrm{ViD}$, vitamin D; OPG, osteoprotogerin; CaSR, calcium-sensing receptor; Mg, magnesium; AGE, advanced-glycosylation end products; Wnt, canonical Wnt-signalling cascade; OCY, osteocyte; OBL, osteoblast; OCL, osteoclast; IL-1, interleukin-1; TNF- $\alpha$, tumour necrosis factor $\alpha$.

and activity in vitro [66]. In addition, hyperglycaemia contributes to increased secretion of sclerostin by the osteocytes. Sclerostin inhibits the Wnt-cascade that is critical for osteoblastogenesis [67].

\section{Osteocyte Function in T1DM}

Osteocyte function, assessed by the secretion of sclerostin is profoundly disturbed in T1DM. Sclerostin is a protein encoded by the SOST-gene that acts as an inhibitor of classical Wnt-signalling cascade with important effects on modelling and remodelling. In modelling, it prevents de novo bone formation [68]. In children with T1DM, a few studies have reported elevated levels of sclerostin [69-71]. Suggested mechanisms for higher sclerostin lev- 
els in individuals with T1DM include hyperglycaemia and elevated levels of advanced glycation end products [71]. Streptozotocin has been used to create a mouse model of insulin deficiency similar to T1DM. In line with data in humans, the streptozotocin-induced T1DM mice showed a lower bone mass, reduced sensitivity to mechanical loading, increased bone formation, reduced bone resorption, increased apoptosis of osteocytes, and increased sclerostin levels. These negative outcomes were partially rescued by 2 different peptides of PTHrP [72]. Taken together, these findings strongly support the hypothesis that impaired osteocyte function plays a key role in diabetic bone disease.

\section{PTH-Vitamin D Axis}

PTH-levels may be low or hypo-responsive in adults with diabetes [8], in line with the low bone turnover status. Hypomagnesaemia-related modulation of the calcium-sensing receptor sensitivity may contribute to relative hypoparathyroidism contributing to low bone turnover $[73,74]$. However, data in the paediatric population are lacking.

Vitamin D deficiency is common in youth with T1DM over a wide range of geographic latitudes. In an Australian study $\left(27.5^{\circ} \mathrm{S}\right), 10 \%$ of the participants were vitamin $\mathrm{D}$ deficient and the mean $25-\mathrm{OH}-\mathrm{D}_{3}$ level was significantly lower in children with T1DM than in controls $(p<$ $0.002)$ [75]. In a Swiss cohort $\left(46.6^{\circ} \mathrm{N}\right) 60 \%$ of the participants were vitamin $\mathrm{D}$ deficient by the end of summer [76].

Generally, vitamin D supplements do not improve bone mass in vitamin $\mathrm{D}$ sufficient children. However, according to 2 Cochrane Reviews in children with $25-\mathrm{OH}-$ $\mathrm{D}_{3}$ levels below $35 \mathrm{nmol} / \mathrm{L}$, an increase in total body $\mathrm{BMC}$ and lumbar spine BMD of $\sim 2 \%$ over a follow-up time of 1-2 years was recorded upon supplementation [77, 78]. Therefore, adequate supply of vitamin $\mathrm{D}$ seems an important factor to limit diabetic bone disease.

\section{Role of Microvascular Disease}

In a prospective study over 7 years, Campos-Pastor et al. [79] showed that adults with T1DM with microvascular disease had progressive bone loss despite good glycaemic control. Although the implication of microvascular disease in diabetic bone disease remains controversial, there is accumulating evidence that microvascular disease may be responsible for bone loss late in the course of T1DM [47]. A two-phase model for T1DM has been suggested by Shanbhogue et al.[47]: In the first phase, immediately after diagnosis, there is rapid bone loss, which de-

Type 1 Diabetes and Bone Health clines in the following years eventually reaching a through. The second phase is initiated by the onset of microvascular disease and is characterized by a further decline of bone mass [47]. Differences between trabecular and cortical remodelling may explain why the trabecular compartment is more involved in the first phase and the cortical compartment more in the second phase of the disease. Since cortical remodelling essentially depends on vascular pericytes as a source for osteoprogenitor cells, microvascular damage results in cortical bone loss due to a lack of osteoblast precursors. In contrast, the trabecular compartment is less affected because of available alternatives including bone lining cells $[47,80]$.

\section{Conclusions}

In summary, studies assessing bone health in children with T1DM with DXA showed conflicting results, related to physical properties of the DXA method as well as due to low sample size in many studies. Newer, non-invasive techniques including pQCT and HRpQCT have shown that children with T1DM have reduced bone mass affecting mainly the trabecular compartment that results in a disturbed microarchitecture and reduced bone strength.

Studies on fracture risk in children with T1DM are lacking. However, the negative effect on trabecular bone mass in a particularly sensitive time window during adolescence is likely to have a negative impact on PBM attainment leading to increased fracture risk in young adulthood.

Consistent with studies in adults, low bone turnover status is critical for diabetic bone disease in children with T1DM. Low bone turnover status in children with T1DM can be explained by several mechanisms including reduced osteoblast formation and function, osteocyte dysfunction and subsequent increased sclerostin levels, and a high prevalence of vitamin $\mathrm{D}$ deficiency.

Taking into account, these observations in diabetic youth, advice for a healthy lifestyle including regular weight-bearing exercise, avoiding smoking, a sufficient calcium intake and, if necessary, vitamin D supplementation should be standard of care. Also, we propose that the assessment of bone health using pQCT and screening for vitamin $\mathrm{D}$ deficiency should be implemented in new guidelines.

Finally, we think that sufficiently powered longitudinal cohort studies assessing bone health in children with T1DM and controls, using both HRpQCT and an array of biochemical parameters of bone turnover and the 
PTH-vitamin D axis are required to (i) better understand the underlying pathophysiological mechanisms for diabetic bone disease and (ii) to detect preventive methods.

\section{Acknowledgments}

The authors are grateful to Prof. Christa E. Flück for her critical review of the manuscript.

\section{Conflict of Interest Statement}

The authors have no conflicts of interest to declare.

\section{Funding Sources}

There were no funding sources for this work.

\section{Author Contributions}

M.J. conceived, designed, and drafted the work. M.J. and C.S. revised it for important intellectual content and gave the final approval of the version to be published. All the authors agreed to be accountable for all aspects of the work in ensuring that questions related to the accuracy or integrity of any part of the work are appropriately investigated and resolved.

\section{References}

1 IDF. IDF diabetes atlas. 9th edn. Brussels, Belgium: International Diabetes Federation; 2019.

2 DiMeglio LA, Evans-Molina C, Oram RA. Type 1 diabetes. Lancet. 2018;391(10138): 2449-62.

3 Crossen S, Xing G, Hoch JS. Changing costs of type 1 diabetes care among US children and adolescents. Pediatr Diabetes. 2020;21(4): 644-8.

4 Warriner AH, Patkar NM, Curtis JR, Delzell E, Gary L, Kilgore M, et al. Which fractures are most attributable to osteoporosis? J Clin Epidemiol. 2011;64(1):46-53.

5 Harvey N, Dennison E, Curtis E, Cooper C. The epidemiology of osteoporotic fractures. In: Bilezekian JP, editor. Primer on the metabolic bone diseases and disorders of mineral metabolism. 9th edn. Hoboken, NJ: WileyBlackwell; 2019.

6 Pan H, Wu N, Yang T, He W. Association between bone mineral density and type 1 diabetes mellitus: a meta-analysis of cross-sectional studies. Diabetes Metab Res Rev. 2014;30(7): $531-42$.

7 Shanbhogue VV, Hansen S, Frost M, Jørgensen NR, Hermann AP, Henriksen JE, et al. Bone geometry, volumetric density, microarchitecture, and estimated bone strength assessed by HR-pQCT in adult patients with type 1 diabetes mellitus. J Bone Miner Res. 2015;30(12):2188-99.

8 Napoli N, Chandran M, Pierroz DD, Abrahamsen B, Schwartz AV, Ferrari SL. Mechanisms of diabetes mellitus-induced bone fragility. Nat Rev Endocrinol. 2017;13(4):20819.

9 Janghorbani M, Feskanich D, Willett WC, Hu F. Prospective study of diabetes and risk of hip fracture: the Nurses' Health Study. Diabetes Care. 2006;29(7):1573-8.

10 Murray CE, Coleman CM. Impact of diabetes mellitus on bone health. Int J Mol Sci. 2019; 20(19):4873.
11 Zhu Q, Xu J, Zhou M, Lian X, Xu J, Shi J. Association between type 1 diabetes mellitus and reduced bone mineral density in children: a meta-analysis. Osteoporosis Int. 2021;32(6): 1143-52.

12 de Souza KSC, Ururahy MAG, da Costa Oliveira YM, Loureiro MB, da Silva HPV, Bortolin RH, et al. Low bone mineral density in patients with type 1 diabetes: association with reduced expression of IGF1, IGF1R and TGFBlin peripheral blood mononuclear cells. Diabetes Metab Res Rev. 2016;32(6): 589-95.

13 Tsentidis C, Gourgiotis D, Kossiva L, Doulgeraki A, Marmarinos A, Galli-Tsinopoulou A, et al. Higher levels of s-RANKL and osteoprotegerin in children and adolescents with type 1 diabetes mellitus may indicate increased osteoclast signaling and predisposition to lower bone mass: a multivariate cross-sectional analysis. Osteoporosis Int. 2016;27(4):1631-43.

14 Loureiro MB, Ururahy MAG, de Souza KSC, da Costa Oliveira YM, da Silva HPV, Bortolin $\mathrm{RH}$, et al. Relationship between glycemic control and OPG gene polymorphisms with lower bone mineral density in patients with type 1 diabetes mellitus. Braz J Pharm Sci. 2017; 53(4).

15 Dongare-Bhor S, Lohiya N, Maheshwari A, Ekbote V, Chiplonkar S, Padidela R, et al. Muscle and bone parameters in underprivileged Indian children and adolescents with T1DM. Bone. 2020;130:115074.

16 Gunczler P, Lanes R, Paoli M, Martinis R, Villaroel $\mathrm{O}$, Weisinger JR. Decreased bone mineral density and bone formation markers shortly after diagnosis of clinical type 1 diabetes mellitus. J Pediatr Endocrinol Metab. 2001;14(5):525-8.
17 Brandao FR, Vicente EJ, Daltro CH, Sacramento M, Moreira A, Adan L. Bone metabolism is linked to disease duration and metabolic control in type 1 diabetes mellitus. Diabetes Res Clin Pract. 2007;78(3):334-9.

18 Maggio ABR, Ferrari S, Kraenzlin M, Marchand LM, Schwitzgebel V, Beghetti M, et al. Decreased bone turnover in children and adolescents with well controlled type 1 diabetes. J Pediatr Endocrinol Metab. 2010;23(7):697708.

19 Simmons KM, McFann K, Taki I, Liu E, Klingensmith GJ, Rewers MJ, et al. Reduced bone mineral density is associated with celiac disease autoimmunity in children with type 1 diabetes. J Pediatrics. 2016;169:44-8.e1.

20 Roh JG, Yoon JS, Park KJ, Lim JS, Lee HS, Hwang JS. Evaluation of bone mineral status in prepuberal children with newly diagnosed type 1 diabetes. Ann Pediatr Endocrinol Metab. 2018;23(3):136-40.

21 Adams JE, Engelke K, Zemel BS, Ward KA, Densitometryof ISC. Quantitative computer tomography in children and adolescents: the 2013 ISCD pediatric official positions. J Clin Densitom. 2014;17(2):258-74.

22 Moyer-Mileur LJ, Dixon SB, Quick JL, Askew EW, Murray MA. Bone mineral acquisition in adolescents with type 1 diabetes. J Pediatr. 2004;145(5):662-9.

23 Heap J, Murray MA, Miller SC, Jalili T, Moyer-Mileur LJ. Alterations in bone characteristics associated with glycemic control in adolescents with type 1 diabetes mellitus. J Pediatr. 2004;144(1):56-62.

24 Pham-Short A, Donaghue KC, Ambler G, Briody J, Garnett S, Munns CF, et al. Abnormal cortical and trabecular bone in youth with type 1 diabetes and celiac disease. Diabetes Care. 2019;42(8):1489-95. 
25 Wagh A, Ekbote V, Khadilkar V, Khadilkar A. Trabecular bone score has poor association with $\mathrm{PQCT}$ derived trabecular bone density in indian children with type 1 diabetes and healthy controls. J Clin Densitom. 2021 AprJun;24(2):268-74.

26 Bechtold S, Dirlenbach I, Raile K, Noelle V, Bonfig W, Schwarz HP. Early manifestation of type 1 diabetes in children is a risk factor for changed bone geometry: data using peripheral quantitative computed tomography. Pediatrics. 2006;118(3):e627-34.

27 Loxton P, Narayan K, Munns CF, Craig ME. Bone mineral density and type 1 diabetes in children and adolescents: a meta-analysis. Diabetes Care. 2021;44(8):1898-905.

28 Rizzoli R, Bianchi ML, Garabédian M, Mckay HA, Moreno LA. Maximizing bone mineral mass gain during growth for the prevention of fractures in the adolescents and the elderly. Bone. 2010 Feb;46(2):294-305.

29 Bailey DA, Mckay HA, Mirwald RL, Crocker PRE, Faulkner RA. A six-year longitudinal study of the relationship of physical activity to bone mineral accrual in growing children: the University of Saskatchewan bone mineral accrual study. J Bone Miner Res. 1999;14(10): 1672-9.

30 Baxter-Jones AD, Faulkner RA, Forwood MR, Mirwald RL, Bailey DA. Bone mineral accrual from 8 to 30 years of age: an estimation of peak bone mass. J Bone Miner Res. 2011;26(8):1729-39.

31 Theintz G, Buchs B, Rizzoli R, Slosman D, Clavien $\mathrm{H}$, Sizonenko PC, et al. Longitudinal monitoring of bone mass accumulation in healthy adolescents: evidence for a marked reduction after 16 years of age at the levels of lumbar spine and femoral neck in female subjects. J Clin Endocrinol Metab. 1992;75(4):1060.

32 Rizzoli R, Bonjour J-P. Determinants of peak bone mass and mechanisms of bone loss. Osteoporos Int. 1999;9(Suppl 2):S17-23.

33 Ammann P, Rizzoli R. Bone strength and its determinants. Osteoporos Int. 2003;14(Suppl 3):S13-8.

34 Madsen JOB, Herskin CW, Zerahn B, Jensen AK, Jørgensen NR, Olsen BS, et al. Unaffected bone mineral density in Danish children and adolescents with type 1 diabetes. J Bone Miner Metab. 2020;38(3):328-37.

35 Weber DR, Gordon RJ, Kelley JC, Leonard MB, Willi SM, Hatch-Stein J, et al. Poor glycemic control is associated with impaired bone accrual in the year following a diagnosis of type 1 diabetes. J Clin Endocrinol Metab. 2019;104(10):4511-20.

36 Chen SC, Shepherd S, McMillan M, McNeilly J, Foster J, Wong SC, et al. Skeletal fragility and its clinical determinants in children with type 1 diabetes. J Clin Endocrinol Metab. 2019;104(8):3585-94.

37 Chobot A, Janota O, Bak-Drabik K, Polanska J, Pluskiewicz W. Bone status in adolescents and young adults with type 1 diabetes: a 10 year longitudinal study. Endokrynol Pol. 2020;71(6):532-8.
38 Fuusager GB, Christesen HT, Milandt N, Schou AJ. Glycemic control and bone mineral density in children and adolescents with type 1 diabetes. Pediatr Diabetes. 2019;20(5): 629-36.

39 Shah VN, Harrall KK, Shah CS, Gallo TL, Joshee P, Snell-Bergeon JK, et al. Bone mineral density at femoral neck and lumbar spine in adults with type 1 diabetes: a meta-analysis and review of the literature. Osteoporos Int. 2017;28(9):2601-10.

40 Thong EP, Herath M, Weber DR, Ranasinha $\mathrm{S}$, Ebeling PR, Milat F, et al. Fracture risk in young and middle-aged adults with type 1 diabetes mellitus: a systematic review and metaanalysis. Clin Endocrinol. 2018;89(3):314-23.

41 Thong EP, Milat F, Enticott JC, Joham AE, Ebeling PR, Mishra GD, et al. The diabetesfracture association in women with type 1 and type 2 diabetes is partially mediated by falls: a 15 -year longitudinal study. Osteoporos Int. 2021;32(6):1175-84.

42 Weber DR, Haynes K, Leonard MB, Willi SM, Denburg MR. Type 1 diabetes is associated with an increased risk of fracture across the life span: a population-based cohort study using the health improvement network (THIN). Diabetes Care. 2015;38(10):1913-20.

43 Champakanath A, Keshawarz A, Pyle L, SnellBergeon JK, Shah VN. Fracture risk assessment (FRAX) without BMD and risk of major osteoporotic fractures in adults with type 1 diabetes. Bone. 2021;143:115614.

44 Clark EM, Ness AR, Bishop NJ, Tobias JH. Association between bone mass and fractures in children: a prospective cohort study. J Bone Miner Res. 2006;21(9):1489-95.

45 Clark EM, Tobias JH, Ness AR. Association between bone density and fractures in children: a systematic review and meta-analysis. Pediatrics. 2006;117(2):e291-7.

46 Samelson EJ, Demissie S, Cupples LA, Zhang $\mathrm{X}, \mathrm{Xu} \mathrm{H}, \mathrm{Liu} \mathrm{C}$, et al. Diabetes and deficits in cortical bone density, microarchitecture, and bone size: framingham HR-pQCT study. J Bone Miner Res. 2018;33(1):54-62.

47 Shanbhogue VV, Hansen S, Frost M, Brixen K, Hermann AP. Bone disease in diabetes: another manifestation of microvascular disease? Lancet Diabetes Endocrinol. 2017;5(10):82738.

48 Saha MT, Sievänen H, Salo MK, Tulokas S, Saha HH. Bone mass and structure in adolescents with type 1 diabetes compared to healthy peers. Osteoporos Int. 2009;20(8): 1401-6.

49 Moyer-Mileur LJ, Slater H, Jordan KC, Murray MA. IGF-1 and IGF-binding proteins and bone mass, geometry, and strength: relation to metabolic control in adolescent girls with type 1 diabetes. J Bone Miner Res. 2008; 23(12):1884-91.

50 Maratova K, Soucek O, Matyskova J, Hlavka Z, Petruzelkova L, Obermannova B, et al. Muscle functions and bone strength are impaired in adolescents with type 1 diabetes. Bone. 2018;106:22-7.
51 Jaworski M, Wierzbicka E, Pludowski P, Szalecki M. Forearm bone density, cross-sectional size and muscle cross-sectional area in adolescents with diabetes mellitus type 1 assessed by peripheral quantitative computed tomography. J Musculoskelet Neuronal Interact. 2019 Aug;19(4):435-47.

52 Clarke B. Normal bone anatomy and physiology. Clin J Am Soc Nephro. 2008;3(Suppl 3): S131-9.

53 Elamin A, Hussein O, Tuvemo T. Growth, puberty, and final height in children with Type 1 diabetes. J Diabetes Complications. 2006;20(4):252-6.

54 Svensson J, Schwandt A, Pacaud D, Beltrand J, Birkebæk NH, Cardona-Hernandez R, et al. The influence of treatment, age at onset, and metabolic control on height in children and adolescents with type 1 diabetes: a SWEET collaborative study. Pediatr Diabetes. 2018; 19(8):1441-50.

55 Devaraja J, Jacques R, Paggiosi M, Clark C, Dimitri P. Impact of type 1 diabetes mellitus on skeletal integrity and strength in adolescents as assessed by HRpQCT. JBMR Plus. 2020;4(11):e10422.

56 Fuusager G, Milandt N, Shanbhogue VV, Hermann AP, Schou AJ, Christesen HT. Lower estimated bone strength and impaired bone microarchitecture in children with type 1 diabetes. BMJ Open Diabetes Res Care. 2020; 8(1):e001384

57 Mitchell DM, Caksa S, Joseph T, Bouxsein ML, Misra M. Elevated HbAlc is associated with altered cortical and trabecular microarchitecture in girls with type 1 diabetes. J Clin Endocrinol Metab. 2019;105(4):e1648-56.

58 Hygum K, Starup-Linde J, Harsløf T, Vestergaard P, Langdahl BL. Mechanisms in endocrinology: diabetes mellitus, a state of low bone turnover: a systematic review and meta-analysis. Eur J Endocrinol. 2017;176(3):R137-57.

59 Madsen JOB, Jørgensen NR, Pociot F, Johannesen J. Bone turnover markers in children and adolescents with type 1 diabetes: a systematic review. Pediatr Diabetes. 2019;20(5): $510-22$.

60 Madsen JOB, Herskin CW, Zerahn B, Jørgensen NR, Olsen BS, Pociot F, et al. Decreased markers of bone turnover in children and adolescents with type 1 diabetes. Pediatr Diabetes. 2020;21(3):505-14.

61 Szymańska M, Michałus I, Kaszkowiak M, Wyka K, Chlebna-Sokół D, Fendler W, et al. Metabolic bone markers can be related to preserved insulin secretion in children with newly diagnosed type 1 diabetes. Pediatr Endocrinol Diabetes Metab. 2020;26(1):10-6.

62 Amrousy DE, El-Afify D, Shabana A. Relationship between bone turnover markers and oxidative stress in children with type 1 diabetes mellitus. Pediatr Res. 2021;89(4):878-81.

63 Fulzele K, Riddle RC, DiGirolamo DJ, Cao X, Wan C, Chen D, et al. Insulin receptor signaling in osteoblasts regulates postnatal bone acquisition and body composition. Cell. 2010; 142(2):309-19. 
64 Nakasaki M, Yoshioka K, Miyamoto Y, Sasaki T, Yoshikawa H, Itoh K. IGF-I secreted by osteoblasts acts as a potent chemotactic factor for osteoblasts. Bone. 2008;43(5):869-79.

65 Bouillon R, Bex M, Herck EV, Laureys J, Dooms L, Lesaffre E, et al. Influence of age, sex, and insulin on osteoblast function: osteoblast dysfunction in diabetes mellitus. J Clin Endocrinol Metab. 1995 Apr;80(4):1194-202.

66 Cunha JS, Ferreira VM, Maquigussa E, Naves MA, Boim MA. Effects of high glucose and high insulin concentrations on osteoblast function in vitro. Cell Tissue Res. 2014; 358(1):249-56.

67 Tanaka K, Yamaguchi T, Kanazawa I, Sugimoto T. Effects of high glucose and advanced glycation end products on the expressions of sclerostin and RANKL as well as apoptosis in osteocyte-like MLO-Y4-A2 cells. Biochem Biophys Res Commun. 2015;461(2):193-9.

68 Moester MJC, Papapoulos SE, Löwik CWGM, Bezooijen RL. Sclerostin: current knowledge and future perspectives. Calcif Tissue Int. 2010 May;87(2):99-107.

69 Faienza MF, Ventura A, Delvecchio M, Fusillo A, Piacente L, Aceto G, et al. High sclerostin and dickkopf-1 (DKK-1) serum levels in children and adolescents with type 1 diabetes mellitus. J Clin Endocrinol Metab. 2016;102(4):1174-81.

70 Wędrychowicz A, Sztefko K, Starzyk JB. Sclerostin and its significance for children and adolescents with type 1 diabetes mellitus (T1D). Bone. 2019;120:387-92.

71 Gortázar AR, Ardura JA. Osteocytes and diabetes: altered function of diabetic osteocytes. Curr Osteoporos Rep. 2020;18(6):796-802.

72 Maycas M, McAndrews KA, Sato AY, Pellegrini GG, Brown DM, Allen MR, et al. PTHrP-derived peptides restore bone mass and strength in diabetic mice: additive effect of mechanical loading. J Bone Miner Res. 2017;32(3):486-97.

73 Thalassinos NC, Hadjiyanni P, Tzanela M, Alevizaki C, Philokiprou D. Calcium metabolism in diabetes mellitus: effect of improved blood glucose control. Diabet Med. 1993 Jun; 10(4):341-4.

74 McNair P, Christensen MS, Madsbad S, Christiansen C, Transbøl I. Hypoparathyroidism in diabetes mellitus. Acta Endocrinol. 1981;96(1):81-6.

75 Greer RM, Portelli SL, Hung BS, Cleghorn GJ, McMahon SK, Batch JA, et al. Serum vitamin
D levels are lower in Australian children and adolescents with type 1 diabetes than in children without diabetes. Pediatr Diabetes. 2013; 14(1):31-41.

76 Janner M, Ballinari P, Mullis PE, Flück CE. High prevalence of vitamin $\mathrm{D}$ deficiency in children and adolescents with type 1 diabetes. Swiss Med Wkly. 2010;140(3536):w13091.

77 Winzenberg T, Powell S, Shaw KA, Jones G. Effects of vitamin D supplementation on bone density in healthy children: systematic review and meta-analysis. BMJ. 2011 Jan;342: c7254.

78 Winzenberg TM, Powell S, Shaw KA, Jones G. Vitamin D supplementation for improving bone mineral density in children. Cochrane Database Syst Rev. 2010;10:CD006944.

79 Campos-Pastor MM, López-Ibarra PJ, Escobar-Jiménez F, Serrano Pardo MD, GarcíaCervigón A. Intensive insulin therapy and bone mineral density in type 1 diabetes mellitus: a prospective study. Osteoporos Int. 2000;11(5):455-9.

80 Parfitt AM. Osteonal and hemi-osteonal remodeling: the spatial and temporal framework for signal traffic in adult human bone. J Cell Biochem. 1994;55(3):273-86. 